\title{
An advanced scheme for wet scavenging and liquid-phase chemistry in a regional online-coupled chemistry transport model
}

\author{
C. Knote ${ }^{1,2, *}$ and D. Brunner ${ }^{1,2}$ \\ ${ }^{1}$ Laboratory for Air Pollution/Env. Technology, Empa Materials and Science, Duebendorf, Switzerland \\ ${ }^{2} \mathrm{C}_{2} \mathrm{SM}$ Center for Climate Systems Modeling, ETH, Zurich, Switzerland \\ *now at: Atmospheric Chemistry Division, National Center for Atmospheric Research, Boulder, CO, USA
}

Correspondence to: C. Knote (knote@ucar.edu)

Received: 12 August 2012 - Published in Atmos. Chem. Phys. Discuss.: 5 October 2012

Revised: 25 January 2013 - Accepted: 29 January 2013 - Published: 1 February 2013

\begin{abstract}
Clouds are reaction chambers for atmospheric trace gases and aerosols, and the associated precipitation is a major sink for atmospheric constituents. The regional chemistry-climate model COSMO-ART has been lacking a description of wet scavenging of gases and aqueous-phase chemistry. In this work we present a coupling of COSMOART with a wet scavenging and aqueous-phase chemistry scheme. The coupling is made consistent with the cloud microphysics scheme of the underlying meteorological model COSMO. While the choice of the aqueous-chemistry mechanism is flexible, the effects of a simple sulfur oxidation scheme are shown in the application of the coupled system in this work. We give details explaining the coupling and extensions made, then present results from idealized flow-over-hill experiments in a 2-D model setup and finally results from a full 3-D simulation. Comparison against measurement data shows that the scheme efficiently reduces $\mathrm{SO}_{2}$ trace gas concentrations by $0.3 \mathrm{ppbv}(-30 \%)$ on average, while leaving $\mathrm{O}_{3}$ and $\mathrm{NO}_{\mathrm{x}}$ unchanged. $\mathrm{PM}_{10}$ aerosol mass was increased by $10 \%$ on average. While total $\mathrm{PM}_{2.5}$ changes only little, chemical composition is improved notably. Overestimations of nitrate aerosols are reduced by typically $0.5-1 \mu \mathrm{g} \mathrm{m}^{-3}$ (up to $-2 \mu \mathrm{g} \mathrm{m}^{-3}$ in the Po Valley) while sulfate mass is increased by $1-1.5 \mu \mathrm{g} \mathrm{m}^{-3}$ on average (up to $2.5 \mu \mathrm{g} \mathrm{m}^{-3}$ in Eastern Europe). The effect of cloud processing of aerosols on its size distribution, i.e. a shift towards larger diameters, is observed. Compared against wet deposition measurements the system tends to underestimate the total wet deposited mass for the simulated case study.
\end{abstract}

\section{Introduction}

Clouds are reaction chambers for trace gases and aerosols in the atmosphere. Their aqueous-phase facilitates chemical reactions like the oxidation of sulfur (Hegg and Hobbs, 1978; Walcek and Taylor, 1986) or organic compounds (Lim et al., 2010; Ervens et al., 2011) which contribute substantially to gas-to-particle transfer (Feichter et al., 1996; Zhang et al., 1999; Rasch et al., 2000). Aerosols are on average subject to 3 condensation/evaporation cycles before being removed from the atmosphere (Pruppacher and Jaenicke, 1995). This cloud processing of aerosols influences size distribution and chemical properties (Wurzler et al., 2000; Lim et al., 2005; Ervens et al., 2008), and therefore their effects on cloud formation (Feingold and Kreidenweis, 2000). Associated precipitation leads to a vertical redistribution of gases and aerosols, and represents through wet deposition a major removal mechanism for air pollutants from the atmosphere.

Numerical chemical transport models (CTMs) are used to describe the chemical composition of the atmosphere and are invaluable tools to improve our understanding of atmospheric processes, for the analysis of past air pollution events, for chemical weather forecasting, or for assessing the efficiency of emission reduction measures. To accurately describe the fate of trace gases and aerosols in the atmosphere, these models need to contain a sufficiently detailed formulation of the processes alluded to above. COSMO-ART (Vogel et al., 2009) is a recently developed regional CTM which currently includes wet scavenging of aerosols but lacks a parametrization of aqueous-phase chemistry and wet deposition of gases. 
Previous evaluation efforts (Knote et al., 2011) showed the necessity to include these processes.

In this work we describe the coupling of the comprehensive wet scavenging and aqueous-phase chemistry scheme SCAV (Tost et al., 2006) with COSMO-ART. SCAV includes descriptions of the scavenging of both gases and aerosols, liquid-phase chemistry and a simple cloud processing of aerosols (in the sense of a mass transfer from smaller to larger particles). It had been originally developed for global models, making assumptions that are not reasonable for kilometer-scale regional modeling.

In Sect. 2 we present an extended system which includes a prognostic treatment of cloud and precipitation chemical composition and which is linked to the COSMO microphysics scheme to derive condensation, transfer, and evaporation rates as well as to describe the precipitation sedimentation term. Section 3 shows results of idealized twodimensional simulations of the flow over a hill to study the interplay of the different components. Section 4 presents a comparison of a realistic 3-D simulation over the European domain with results obtained in a previous evaluation study of COSMO-ART without aqueous-phase chemistry. Finally we discuss limitations of the coupled system and compare it against implementations of these processes in other regional modeling systems.

\section{Methods}

\subsection{Modeling system}

COSMO-ART (Vogel et al., 2009) is an online-coupled regional chemistry transport model (CTM) developed at KIT Karlsruhe, Germany. It is based on the numerical weather prediction (NWP) system of the Consortium for Small-Scale Modeling (COSMO model, Baldauf et al., 2011). COSMO has been extended to optionally simulate Aerosols and Reactive Trace gases (ART). Aerosols are represented by the modal aerosol module MADEsoot extended (Ackermann et al., 1998; Riemer et al., 2003) employing five different interacting modes (2 Aitken, 2 accumulation, 1 fresh soot) for the description of fine particulate matter and explicit aging of soot particles (Riemer et al., 2004). One pair of Aitken and accumulation modes is called "fresh", as it has no soot core, while the other pair, the "mixed" Aitken and accumulation modes, includes soot. Additional modes describe coarse particles ( 1 mode), dust ( 3 modes) and seasalt ( 3 modes). Table 1 gives an overview of the aerosol module. For each mode, mass contributions and total number concentration are prognostic quantities, while the standard deviation is fixed. A washout scheme for aerosols was already included based on the work of Rinke (2008). The Regional Acid Deposition Model, Version 2 (RADM2, Stockwell et al., 1990) is used for gas-phase chemistry in a modified version (RADMKA) that has been extended to include the more comprehensive isoprene chemistry of Geiger et al. (2003). Formation of secondary organic aerosol components is realized with a volatility basis set (Donahue et al., 2006) approach described in Athanasopoulou et al. (2013). ISORROPIA II (Fountoukis and Nenes, 2007) is used to calculate thermodynamic equilibrium of the $\mathrm{NH}_{4}^{+}-\mathrm{SO}_{4}^{2-}-\mathrm{NO}_{3}^{-}-\mathrm{H}_{2} \mathrm{O}$ aerosol system. New particle formation is simulated according to Kerminen and Wexler (1994) considering binary homogeneous nucleation of $\mathrm{H}_{2} \mathrm{SO}_{4}$. The model has been thoroughly evaluated in Knote et al. (2011).

\subsection{Scavenging and aqueous-phase chemistry scheme}

The SCAV module (Tost et al., 2006) was developed to describe the transfer of gases and particulate matter between air, cloud droplets and rain drops. It follows the Modular Earth Submodel System (MESSy, Jöckel et al., 2005) standard.

Transfer of trace gases between air and droplet is represented by explicitly calculating the transport processes rather than relying on pre-calculated (effective) Henry's law coefficients. Chemical reactions in the aqueous-phase are solved together with the transfer reactions using the Kinetic PreProcessor (KPP, Damian et al., 2002). Chemical components dissolved from aerosols (e.g. $\mathrm{SO}_{4}^{2-}, \mathrm{NO}_{3}^{-}$) are also considered in liquid-phase reactions. The use of KPP allows for a flexible adaptation of the chemistry scheme. In the simulations presented here, a set of reactions based on MECCA (Sander et al., 2005) is used which focuses on sulfur oxidation. It describes dissolution and subsequent dissociation for several inorganic and organic compounds and the oxidation of sulfur by $\mathrm{O}_{3}$ and $\mathrm{H}_{2} \mathrm{O}_{2}$. A complete list of the gas-to-droplet transfer reactions, acid-base equilibria and aqueous-phase reactions included in this scheme are given in Tables 2, 3 and 4, respectively.

Aerosols are scavenged into cloud droplets employing an empirically derived, size-dependent scavenging curve representing cloud condensation nuclei $(\mathrm{CCN})$ activation ("nucleation and growth"-parameterization, Eq. 9 in Tost et al., 2006), and Brownian motion following Seinfeld and Pandis (2006). Impaction scavenging by rain droplets is realized according to Slinn (1984) taking into account both particle and rain droplet size. No distinction is made between incloud and below-cloud scavenging, hence scavenging by rain droplets can be active also within clouds. Thereby seederfeeder type clouds are more realistically represented.

Upon complete evaporation of a droplet, aerosols (and the newly created ions) are released back into the largest soluble mode. This "cloud processing", that is the transfer of mass into the largest soluble mode, is based on the assumption that upon evaporation of a cloud droplet all (small) particles that might have been scavenged during the lifetime of the cloud by a single cloud droplet will stick together and form one single particle upon release.

The module makes use of current environmental quantities (temperature, pressure, water vapor content, cloud liquid 
Table 1. Aerosol modes in COSMO-ART, their constituents, targets for release upon droplet evaporation, and whether the mode participates in nucleation scavenging.

\begin{tabular}{lllll}
\hline name & description & constituents & evap. target (mass frac.) & nuc. scav.? \\
\hline $\mathrm{I}$ & fresh Aitken & $\mathrm{SO}_{4}^{2-}, \mathrm{NH}_{4}^{+}, \mathrm{NO}_{3}^{-}, \mathrm{POA}, \mathrm{SOA}, \mathrm{unspec}, \mathrm{H}_{2} \mathrm{O}$ & $0.1 \cdot \mathrm{Im}, 0.9 \cdot \mathrm{Jm}$ & yes \\
$\mathrm{J}$ & fresh accum. & $\mathrm{SO}_{4}^{2-}, \mathrm{NH}_{4}^{+}, \mathrm{NO}_{3}^{-}, \mathrm{POA}, \mathrm{SOA}, \mathrm{unspec}, \mathrm{H}_{2} \mathrm{O}$ & $0.1 \cdot \mathrm{Im}, 0.9 \cdot \mathrm{Jm}$ & yes \\
$\mathrm{Im}$ & mixed Aitken & $\mathrm{SO}_{4}^{2-}, \mathrm{NH}_{4}^{+}, \mathrm{NO}_{3}^{-}, \mathrm{POA}, \mathrm{SOA}$, soot, $\mathrm{H}_{2} \mathrm{O}$ & $0.1 \cdot \mathrm{Im}, 0.9 \cdot \mathrm{Jm}$ & yes \\
$\mathrm{Jm}$ & mixed accum. & $\mathrm{SO}_{4}^{2-}, \mathrm{NH}_{4}^{+}, \mathrm{NO}_{3}^{-}, \mathrm{POA}$, soot, $\mathrm{H}_{2} \mathrm{O}$ & $0.1 \cdot \mathrm{Im}, 0.9 \cdot \mathrm{Jm}$ & yes \\
SOOT & fresh soot & soot & $1.0 \cdot \mathrm{SOOT}$ & no \\
ANTHA & anth. coarse & unspec. & $1.0 \cdot$ ANTHA & yes \\
SEASA & fine sea salt & sea salt, $\mathrm{SO}_{4}^{2-}, \mathrm{H}_{2} \mathrm{O}$ & $1.0 \cdot$ SEASA & yes \\
SEASB & medium sea salt & sea salt, $\mathrm{SO}_{4}^{2-}, \mathrm{H}_{2} \mathrm{O}$ & $1.0 \cdot$ SEASB & yes \\
SEASC & coarse sea salt & sea salt, $\mathrm{SO}_{4}^{2-}, \mathrm{H}_{2} \mathrm{O}$ & $1.0 \cdot$ SEASC & yes \\
SOILA & fine dust & dust & $1.0 \cdot$ SOILA & yes \\
SOILB & medium dust & dust & $1.0 \cdot$ SOILB & yes \\
SOILC & coarse dust & dust & $1.0 \cdot$ SOILC & yes \\
\hline
\end{tabular}

"SOA" above are actually 4 species representing different volatility bins. "unspec." refers to chemically unspeciated mass.

Table 2. Gas-to-liquid transfer reactions considered.

\begin{tabular}{|c|c|c|}
\hline reaction & & \\
\hline $\mathrm{O}_{3}$ & $\leftrightharpoons$ & $\mathrm{O}_{3}(\mathrm{aq})$ \\
\hline $\mathrm{H}_{2} \mathrm{O}_{2}$ & $\leftrightharpoons$ & $\mathrm{H}_{2} \mathrm{O}_{2}(\mathrm{aq})$ \\
\hline $\mathrm{NH}_{3}$ & $\leftrightharpoons$ & $\mathrm{NH}_{3}(\mathrm{aq})$ \\
\hline $\mathrm{HNO}_{3}$ & $\leftrightharpoons$ & $\mathrm{HNO}_{3}(\mathrm{aq})$ \\
\hline $\mathrm{CO}_{2}$ & $\leftrightharpoons$ & $\mathrm{CO}_{2}(\mathrm{aq})$ \\
\hline $\mathrm{HCHO}$ & $\leftrightharpoons$ & $\mathrm{HCHO}(\mathrm{aq})$ \\
\hline $\mathrm{HCOOH}$ & $\leftrightharpoons$ & $\mathrm{HCOOH}(\mathrm{aq})$ \\
\hline $\mathrm{CH}_{3} \mathrm{OOH}$ & $\leftrightharpoons$ & $\mathrm{CH}_{3} \mathrm{OOH}(\mathrm{aq})$ \\
\hline $\mathrm{CH}_{3} \mathrm{COOH}$ & $\leftrightharpoons$ & $\mathrm{CH}_{3} \mathrm{COOH}(\mathrm{aq})$ \\
\hline $\mathrm{HCl}$ & $\leftrightharpoons$ & $\mathrm{HCl}(\mathrm{aq})$ \\
\hline $\mathrm{HBr}$ & $\leftrightharpoons$ & $\operatorname{HBr}(\mathrm{aq})$ \\
\hline $\mathrm{SO}_{2}$ & $\leftrightharpoons$ & $\mathrm{SO}_{2}(\mathrm{aq})$ \\
\hline $\mathrm{H}_{2} \mathrm{SO}_{4}$ & $\rightarrow$ & $\mathrm{H}_{2} \mathrm{SO}_{4}(\mathrm{aq})$ \\
\hline
\end{tabular}

Note that the gas-droplet equilibria above are considered as two separate reactions in SCAV, with forward and backward rate coefficients calculated online, Tost et al. (2006).

water content (cLWC), rain water content, rain flux) as given by the driving meteorological model. Treatment of ice-phase processes is included in SCAV, but not used in our coupling.

\subsection{Coupling and extension}

In the original formulation of SCAV the complete life-cycle of a cloud (condensation, scavenging, aqueous-phase chemistry, washout by precipitation, evaporation) was simulated each time-step. This avoided the need to make the chemical composition of the liquid-phase transported quantities, allowed to use a time-independent activation parameterization for aerosols, and greatly improved the computational efficiency of the scheme. The COSMO-ART modeling system is operated on the meso- $\gamma$ scale (Orlanski, 1975), with mesh sizes down to $1 \mathrm{~km}$. On this scale, the lifetime of a cloud (10-30 min for shallow cumuli (Zhao and Austin, 2005) and thunderstorm cells (Cotton et al., 2011), up to several hours for stratiform clouds (Albrecht, 1989)) is well above typical model time-steps (several seconds to minutes). The meteorological core COSMO reflects this by treating cLWC and rain water content as prognostic quantities (Baldauf et al., 2011). To consistently represent this also in the -ART part, a description of partial condensation and evaporation was necessary for the coupling, which in turn required prognostic transport of quantities within the aqueous-phase, both in cloud and rain water. As COSMO-ART is an online-coupled modeling system all transport processes applied to rain and precipitation are now likewise applied to its chemical composition, employing exactly the same operators and methods. In this work, the coupling is done for grid-scale clouds and precipitation.

The following section describes how aerosols interact with clouds and precipitation in the new coupled system. First, the methods employed in the COSMO meteorological core are briefly outlined, followed by a description of the treatment of cloud interactions. Finally we describe how precipitation is considered. The description is focused on the treatment of aerosols, as the interactions of trace gases with clouds as well as with precipitation are done using the kinetic transfer method already described in Tost et al. (2006), which is employed unchanged.

\subsubsection{COSMO operational cloud and precipitation microphysics}

A physically explicit description of the interactions with hydrometeors requires information (e.g. droplet number concentration and size distribution) which, while included in COSMO in a research version (Seifert and Beheng, 2006), 
Table 3. Acid-base and other equilibrium reactions.

\begin{tabular}{lllll}
\hline reaction & & & $K_{0}(M)$ & $-\Delta H / R(K)$ \\
\hline $\mathrm{H}_{2} \mathrm{O}(\mathrm{aq})$ & $\leftrightharpoons$ & $\mathrm{H}^{+}+\mathrm{OH}^{-}$ & $1.0 \times 10^{-16}$ & -6716 \\
$\mathrm{NH}_{4}^{+}(\mathrm{aq})$ & $\leftrightharpoons$ & $\mathrm{H}^{+}+\mathrm{NH}_{3}$ & $5.88 \times 10^{-10}$ & -2391 \\
$\mathrm{HNO}_{3}(\mathrm{aq})$ & $\leftrightharpoons$ & $\mathrm{H}^{+}+\mathrm{NO}_{3}^{-}$ & 15 & 8700 \\
$\mathrm{CO}_{2}(\mathrm{aq})$ & $\leftrightharpoons$ & $\mathrm{H}^{+}+\mathrm{HCO}_{3}^{-}$ & $4.3 \times 10^{-7}$ & -913 \\
$\mathrm{HCOOH}(\mathrm{aq})$ & $\leftrightharpoons$ & $\mathrm{H}^{+}+\mathrm{HCOO}^{-}$ & $1.8 \times 10^{-4}$ & \\
$\mathrm{CH}_{3} \mathrm{COOH}(\mathrm{aq})$ & $\leftrightharpoons$ & $\mathrm{H}^{+}+\mathrm{CH}_{3} \mathrm{COO}^{-}$ & $1.75 \times 10^{-5}$ & -46 \\
$\mathrm{HCl}(\mathrm{aq})$ & $\leftrightharpoons$ & $\mathrm{H}^{+}+\mathrm{Cl}^{-}$ & $1.7 \times 10^{6}$ & 6896 \\
$\mathrm{HBr}(\mathrm{aq})$ & $\leftrightharpoons$ & $\mathrm{H}^{+}+\mathrm{Br}^{-}$ & $1.0 \times 10^{9}$ & \\
$\mathrm{SO}_{2}(\mathrm{aq})$ & $\leftrightharpoons$ & $\mathrm{H}^{+}+\mathrm{HSO}_{3}^{-}$ & $1.7 \times 10^{-2}$ & 2090 \\
$\mathrm{HSO}_{3}^{-}(\mathrm{aq})$ & $\leftrightharpoons$ & $\mathrm{H}^{+}+\mathrm{SO}_{3}^{--}$ & $6.0 \times 10^{-8}$ & 1120 \\
$\mathrm{HSO}_{4}^{-}(\mathrm{aq})$ & $\leftrightharpoons$ & $\mathrm{H}^{+}+\mathrm{SO}_{4}^{2-}$ & $1.2 \times 10^{-2}$ & 2720 \\
$\mathrm{H}_{2} \mathrm{SO}_{4}(\mathrm{aq})$ & $\leftrightharpoons$ & $\mathrm{H}^{+}+\mathrm{HSO}_{4}^{-}$ & $1.0 \times 10^{3}$ & \\
\hline
\end{tabular}

Table 4. Aqueous-phase reactions.

\begin{tabular}{lllll}
\hline reaction & & & $k_{0}\left(M^{-1} s^{-1}\right)$ & $-E_{\mathrm{a}} / R(K)$ \\
\hline $\mathrm{SO}_{3}^{2-}+\mathrm{O}_{3}$ & $\rightarrow$ & $\mathrm{SO}_{4}^{2-}$ & $1.5 \times 10^{9}$ & -5300 \\
$\mathrm{HSO}_{3}^{-}+\mathrm{O}_{3}$ & $\rightarrow$ & $\mathrm{SO}_{4}^{2-}+\mathrm{H}^{+}$ & $3.7 \times 10^{5}$ & -5500 \\
$\mathrm{HSO}_{3}^{-}+\mathrm{H}_{2} \mathrm{O}_{2}$ & $\rightarrow$ & $\mathrm{SO}_{4}^{2-}+\mathrm{H}^{+}$ & $5.2 \times 10^{6}$ & -3650 \\
\hline
\end{tabular}

are not available in the current operational version. It was of interest to create a coupling usable with the current state of COSMO, hence we were restricted to the operational scheme. To approximate these processes in the best way feasible, we try to be as consistent with the treatment of water in the meteorological core as possible:

Grid-scale clouds and precipitation are described in COSMO by a bulk water-continuity model, where the total water content of a grid cell is distributed across a number of reservoirs, and budget equations are solved to redistribute mass between these reservoirs. A typically used setup is the "two category cloud-ice scheme", where 5 types of water are accounted for: water vapor (qv), cloud liquid water (qc), cloud ice (qi), rain (qr) and snow (qs). Each reservoir is then subject to dynamical processes and has a budget equation of its microphysical source and sink terms (Eq. 5.95 in Doms et al., 2011). E.g. for qc it is given as

$S^{\mathrm{c}}=S_{\mathrm{c}}-S_{\mathrm{au}}^{\mathrm{c}}-S_{\mathrm{ac}}-S_{\mathrm{frz}}^{\mathrm{c}}+S_{\mathrm{melt}}^{\mathrm{i}}-S_{\mathrm{rim}}-S_{\text {shed }}$,

where $S_{\mathrm{c}}$ is condensation or evaporation of cloud water, $S_{\mathrm{au}}^{\mathrm{c}}$ the autoconversion of cloud water to form rain, $S_{\mathrm{ac}}$ the accretion of cloud water by raindrops, $S_{\mathrm{frz}}^{\mathrm{c}}$ the nucleation of cloud ice due to freezing of cloud water, $S_{\text {melt }}^{\mathrm{i}}$ the melting of cloud ice, $S_{\text {rim }}$ the collection of cloud water by snow (riming), and $S_{\text {shed }}$ the collection of cloud water by wet snow to form rain (shedding) (Doms et al., 2011).

Almost all microphysical terms in Eq. (1) are calculated once per time-step in a dedicated subroutine, except for the cloud water condensation/evaporation tendency $S_{\mathrm{c}}$. It is calculated with a commonly used saturation-adjustment technique (e.g. Lord et al., 1984; Tao, 1989), where temperature and cloud liquid water in a grid-cell are isobarically adjusted, taking latent heating into account, until saturation is reached. Decreases/increases in specific humidity (qv) then define the flux between water vapour and cloud liquid water (Doms et al., 2011). As several processes act upon the water reservoirs in COSMO (advection, precipitation, relaxation, nudging), this saturation adjustment is applied several times per time-step.

In our coupling we sum the changes made to the reservoirs in each call of the saturation adjustment to derive an accumulated net cloud condensation/evaporation tendency. We also save the other microphysical tendencies described above. At the end of a timestep, after all changes to the water continuum by COSMO are done, the wet scavenging/aqueousphase chemistry routine is called.

\subsubsection{Cloud uptake and release of aerosols}

Aerosol-cloud interactions are a major source of uncertainty in current climate simulations and therefore the subject of intense research (Lohmann and Feichter, 2005). The method presented here does not describe aerosol indirect effects, hence cloud development and lifetime are unaffected by aerosols. These interactions have been implemented in a 
research version by Bangert et al. (2011), and a combination of the two developments is topic of future research.

Activation of aerosols to cloud droplets is parameterized in SCAV applying an empirically derived, sigmoidal-shaped scavenging fraction as function of particle diameter (Eq. 9 in Tost et al., 2006). This function describes the fraction of aerosols originally present before the formation of the cloud that finally ends up in cloud droplets. However, in our approach we need to describe the temporally evolving fraction scavenged at each time step (order seconds to minutes) which only after sufficient time approaches the overall scavenging ratio described by the original scheme. We therefore assume that only a fraction of the aerosol present in the grid cell is subject to the scavenging function.

We assume that aerosols and water vapour are well mixed within each model grid cell. When the saturation adjustment indicates a flux towards cloud liquid water, the fraction of aerosol exposed to scavenging is assumed to equal the fraction $f_{\text {qv2qc }}$ of water vapour lost during a time step.

Furthermore, saturation adjustment does not distinguish fresh nucleation from condensation on existing droplets. Hence only a fraction $\left(f_{\mathrm{flx}}\right)$ of the total flux is to be considered nucleation: if no cLWC exists, all of the flux must be nucleation, as no droplets exist to provide a condensation sink. In contrast, for fully developed clouds and high cLWC, all of the flux is assumed to be condensation on existing particles. In our implementation $f_{\mathrm{flx}}$ therefore scales linearly between no cloud ( $\left.\mathrm{qc}=0.0, f_{\mathrm{flx}}=1.0\right)$ and a fully developed cloud represented by an upper limit of cLWC $\left(\mathrm{qc}=\mathrm{qc}_{\max }, f_{\mathrm{flx}}=0.0\right)$, remaining 0.0 for cloud liquid water contents above $\mathrm{qc}_{\max }$. The upper limit $\mathrm{qc}_{\max }$ is determined based on observed cloud droplet number densities $\left(N_{0}, 200 \mathrm{~cm}^{-3}\right)$, droplet radii $\left(r_{\mathrm{c}}, 8.75 \mu \mathrm{m}\right)$, and water density $\left(\rho_{\mathrm{w}}, 1000 \mathrm{~kg} \mathrm{~m}^{-3}\right)$ as

$\mathrm{qc}_{\max }=N_{0} \cdot 4 / 3 \cdot \pi \cdot r_{\mathrm{c}}^{3} \cdot \rho_{\mathrm{w}}$.

The fraction of aerosols in a grid cell that are subject to the activation parameterization in each timestep $f_{\text {act }}$ is then

$f_{\text {act }}=f_{\mathrm{qv} 2 \mathrm{qc}} \cdot f_{\mathrm{flx}}$.

In the simulations presented here, all modes of the MADE aerosol module (Table 1) except the fresh soot mode (SOOT) can be activated to cloud droplets.

In case the saturation adjustment indicates a flux towards water vapour, a similar method is employed as outlined above: upon evaporation, there is no distinction in the saturation adjustment between evaporation from droplets continuing to exist and complete evaporation with subsequent release of cloud processed aerosols (and a decrease in number of cloud droplets). Again, we use the flux given by the saturation adjustment, this time relating it to the initial cLWC to derive the fraction of liquid-phase species mass subject to evaporation $\left(f_{\mathrm{qc} 2 \mathrm{qv}}\right)$ and apply an additional weight: we assume again that for fully developed clouds and high cLWC, all evaporation is actually only shrinking of existing droplets, while for zero cLWC all droplets evaporate and cloud processed particles are released. Hence, the "particle-releasing" fraction of evaporation is equal to $f_{\mathrm{flx}}$ derived above, and each timestep a fraction

$f_{\text {evap }}=f_{\text {qc2qv }} \cdot f_{\text {flx }}$

of the total liquid-phase species content is released from cloud liquid water.

Upon evaporation, a number of aerosol particles released needs to be given, which is assumed to be the number of evaporated cloud droplets. Cloud droplet number density is not available within COSMO, as it is not needed for the bulk treatment. We hence use a constant amount of $200 \mathrm{~cm}^{-3}$ (the same as used above for maximum cloud water) and calculate the number of evaporating droplets therefrom.

This treatment of evaporation, i.e. using the mass as scavenged, but assigning a number based on the number of cloud droplets, represents "cloud processing of aerosols" in our model. Under the assumption that each cloud or rain droplet will form a single aerosol particle upon evaporation, the aerosol size distribution may be substantially altered as compared to the size distribution upstream of the cloud (Feingold and Kreidenweis, 2000). The question that arises is how to represent this process in a modal scheme like MADE. There, a number of log-normal modes exist which represent Aitken, accumulation and coarse mode particles. If now cloud processing creates an additional mode, a "from-cloud" mode, and one does not intend to represent this new mode in the aerosol-phase additionally to the existing ones, mass and number released from cloud droplets need to be redistributed onto the existing modes. SCAV in its original formulation put mass back into the largest soluble mode (in our case the "mixed" accumulation mode) upon complete evaporation. We slightly refined this by distributing mass and number by equal fractions onto the mixed Aitken (10\%) and accumulation mode $(90 \%)$, assuming that a small fraction of the cloud processed aerosol is still smaller than the accumulation mode size range. The median diameter of a given aerosol mode is proportional to $(\mathrm{M} / \mathrm{N})^{1 / 3}$, where $\mathrm{M}$ is the total mass and $\mathrm{N}$ the number of particles in the mode. The new aerosol produced by cloud evaporation will tend to have a larger ratio $\mathrm{M} / \mathrm{N}$ and hence a larger median diameter than the preexisting aerosol since the mass $\mathrm{M}$ of previously scavenged material (and additionally converted trace gas precursors) is distributed over a comparatively small number $\mathrm{N}$ of evaporated cloud droplets. Due to this treatment both modes are expected to shift to larger diameters. For the anthropogenic coarse mode and all sea salt and dust modes, evaporating aerosol particles are returned to their mode of origin. Table 1 lists the evaporation targets for all modes.

Note that scavenged species that would be released as gases, not aerosols, are in connection with the gas-phase via the kinetic transfer description of Tost et al. (2006) as long 
as the droplet exists, but are released in their entirety upon droplet evaporation.

\subsubsection{Precipitation uptake and release of aerosols}

The effects of precipitation on aerosols in current regionalscale modeling systems is largely based on research done three decades ago (e.g. Slinn, 1984; Volken and Schumann, 1993). Aerosols are incorporated into droplets as a function of particle and droplet size, and precipitation rate, considering Brownian motion, impaction and interception scavenging as underlying physical processes. Precipitation fluxes derived from precipitation rates give the sedimentation flux, and, if considered, a flux divergence indicates rain production/evaporation.

While in many schemes scavenged mass is immediately lost and wet deposited, the treatment of precipitation in today's mescoscale modeling systems would allow for a more comprehensive treatment including evaporation and 3dimensional transport of rain droplets out of a vertical column, as presented e.g. for COSMO in Gassmann (2003); Baldauf and Schulz (2004), for WRF in Hong et al. (2004), or in Lopez (2002) for Arpege.

This is realized in our approach, which additionally deals with the numerical challenge that rain droplets can traverse more than one layer within a time step. The method proposed here overcomes these shortcomings and brings the treatment of aerosols (and gases) in precipitation up to par with the current treatment of precipitation in COSMO-ART. by

The total change of rain water over a time-step $\Delta t$ is given

$\Delta \mathrm{qr}_{\mathrm{tot}}=\Delta \mathrm{qr}_{\mathrm{dyn}}+\Delta \mathrm{qr}_{\mathrm{sed}}+\Delta \mathrm{qr}_{\mathrm{mp}}$,

with $\Delta \mathrm{qr}_{\mathrm{dyn}}$ and $\Delta \mathrm{qr}_{\text {sed }}$ being the contributions by transport (advection, diffusion) and sedimentation, respectively, and $\Delta \mathrm{qr}_{\mathrm{mp}}$ the contribution by microphysics.

Transport, $\Delta \mathrm{qr}_{\mathrm{dyn}}$, is now considered for rain chemical composition as well, as it is a prognostic quantity in our implementation. Sedimentation of rain water in COSMO employs an implicit Crank-Nicholson scheme to account for droplets falling through several model levels within one timestep, considering microphysical processes (autoconversion, accretion, evaporation) during the fall (Doms et al., 2011; Gassmann, 2003). This scheme is also applied to the chemical composition of rain droplets.

Like for cloud liquid water (Eq. 1) there is also a balance equation for rain water (qr), describing the tendency due to all microphysical processes,

$S^{\mathrm{r}}=S_{\mathrm{au}}^{\mathrm{c}}+S_{\mathrm{ac}}-S_{\mathrm{ev}}+S_{\mathrm{shed}}-S_{\mathrm{cri}}^{\mathrm{r}}-S_{\mathrm{frz}}^{\mathrm{r}}+S_{\mathrm{melt}}^{\mathrm{s}}$,

with the additional terms $S_{\mathrm{ev}}$ for evaporation of rain water, $S_{\text {cri }}^{\mathrm{r}}$ and $S_{\text {frz }}^{\mathrm{r}}$ for freezing of rain due to collection of cloud ice/heterogeneous nucleation forming snow, and $S_{\text {melt }}^{\mathrm{s}}$ representing melting of snow.
Scavenging of gases into rain drops and aqueous-phase chemistry are calculated using the kinetic approach discussed in the description of SCAV. Aerosols are transferred into rain drops by applying the (rain-rate-dependent) scavenging function included in SCAV to grid cells with precipitation, employing the rain rate calculated by the COSMO microphysics scheme.

Conversion of cloud water to rain water is the sum of autoconversion, accretion and shedding. This amount, as given by the COSMO microphysics scheme, is used to calculate the transfer of chemical components from cloud to rain water. The evaporation tendency $S_{\mathrm{ev}}$ finally gives the fraction of precipitation evaporation, and hence also the fraction of chemical components in rain drops released. Here again we employ the method described in the last section in which we use the fraction of rain evaporating during a timestep to estimate the corresponding fraction of scavenged chemical mass to be released from the rain phase. The number of aerosols $\left(N_{\mathrm{r}}\right)$ corresponding to the aerosol mass released during rain evaporation is calculated as

$N_{\mathrm{r}}=\frac{\mathrm{qr}}{4 / 3 \cdot \pi \cdot r_{\mathrm{d}}^{3} \cdot \rho_{\mathrm{w}}}$

where $r_{\mathrm{d}}$ is the rain droplet radius following Mason (1971) as in the original SCAV scheme. Weighted with the fraction of evaporating rain water to total rain water content in a cell this then gives the number of evaporated particles. Again, one single aerosol particle is assumed to be released upon evaporation of one rain droplet.

In conclusion, our coupling transports the chemical composition of cloud liquid and precipitating water consistently with the respective quantities in the meteorological part. Evaporation, condensation and cloud-to-rain conversion tendencies from the meteorological core are used to describe the respective scavenging/evaporation processes for chemical components.

\section{Idealized 2-D simulations}

To understand the interplay of the different components of the new scavenging scheme we have set up an idealized 2-D simulation of the flow over a Gaussian hill with a non-precipitating cloud above. The model setup consists of 150 grid points in $x$-direction with a grid spacing of $\mathrm{d} x=0.0045^{\circ}(\approx 500 \mathrm{~m})$ and 40 vertical hybrid sigma levels up to $20 \mathrm{hPa}$. Lateral meteorological forcing is provided as a polytrope atmosphere with three layers: boundary layer $(<2000 \mathrm{~m})$, free troposphere $(<11000 \mathrm{~m})$, and tropopause region. A vertical temperature profile starting at $288.16 \mathrm{~K}$ down to $216.66 \mathrm{~K}$ at the tropopause is prescribed, with vertical gradients of $-0.0095 \mathrm{Km}^{-1}$ and $-0.0065 \mathrm{Km}^{-1}$ in the boundary layer and the free troposphere, respectively, and a vertically constant $u$ wind component of $20 \mathrm{~m} \mathrm{~s}^{-1}$. In the domain center a Gaussian-shaped hill with a height of 


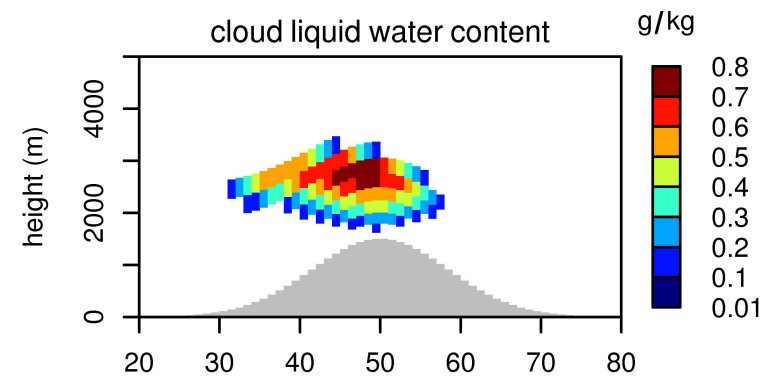

Fig. 1. Cloud liquid water distribution $\left(\mathrm{g} \mathrm{kg}^{-1}\right)$.

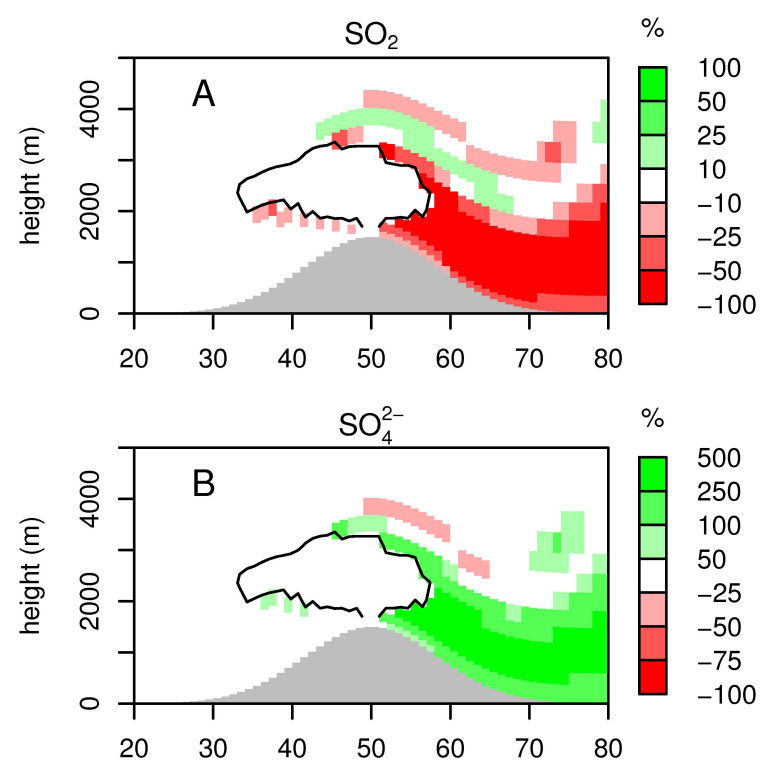

Fig. 2. Changes in gaseous $\mathrm{SO}_{2}$ (A) and total $\mathrm{SO}_{4}^{2-}$ (B) aerosol mass as percent change against the reference simulation.

$1500 \mathrm{~m}$ and a half width diameter of $5000 \mathrm{~m}$ acts as distortion element to the flow field, resulting in cloud development (Fig. 1). Chemical composition (gases and aerosols) at the lateral boundaries is prescribed using an averaged vertical profile of a grid point from a previous 3-D simulation. The composition represents typical conditions at Payerne $(\mathrm{CH})$, a rural site in the Swiss Plateau in autumn at noon time. It is calculated as the mean of all 12:00 UTC profiles at Payerne during the 20 days of simulation of the "autumn" case in Knote et al. (2011). The profile was modified by increases in the concentrations of $\mathrm{H}_{2} \mathrm{O}_{2}$ (factor of 5) and $\mathrm{NH}_{3}$ (factor of 2.5) to ensure that no oxidant or counter-ion limitation occurs. Two simulations have been made, each integrated over $12 \mathrm{~h}$ to allow the system to reach steady state, one without any wet scavenging or aqueous-phase chemistry as a reference simulation (REF), and one including the new coupling.

Figure 2 shows how $\mathrm{SO}_{2}$ is efficiently scavenged after the air has passed the cloud, and that in turn total aerosol sulfate mass has increased by up to $500 \%$. Shown are differences of the mean over the integration period. The time an air par-
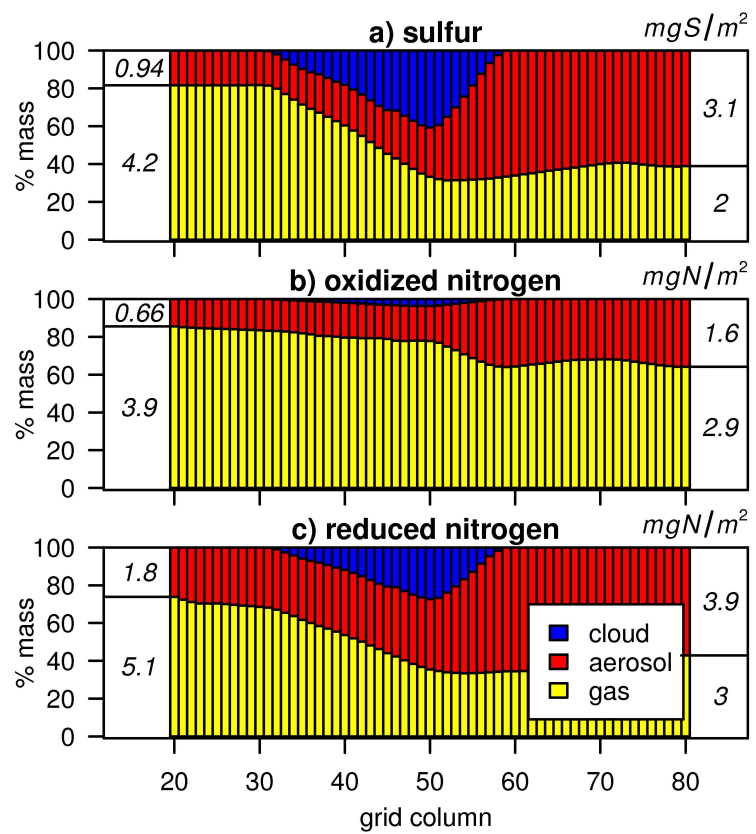

Fig. 3. Partitioning of different groups of compounds between phases during passage of the cloud (between grid columns 30 and 60 of the idealized simulation). Shown are grid column totals. The three phases considered are gas (g), aerosol (a), and cloud liquid water (1). The compound groups are (a) sulfur: $\mathrm{SO}_{2}(\mathrm{~g}), \mathrm{H}_{2} \mathrm{SO}_{4}$ (g), $\mathrm{SO}_{4}^{2-}$ (s), $\mathrm{SO}_{2}$ (l), $\mathrm{H}_{2} \mathrm{SO}_{4}$ (l), $\mathrm{HSO}_{4}^{-}$(l), $\mathrm{SO}_{4}^{2-}$ (l), $\mathrm{HSO}_{3}^{-}$(l), $\mathrm{SO}_{3}^{2-}$ (l). (b) oxidized nitrogen: $\mathrm{NO}(\mathrm{g}), \mathrm{NO}_{2}(\mathrm{~g}), \mathrm{HNO}_{3}(\mathrm{~g}), \mathrm{N}_{2} \mathrm{O}_{5}$ (g), $\mathrm{NO}_{3}(\mathrm{~g}), \mathrm{NO}_{3}^{-}(\mathrm{s}), \mathrm{HNO}_{3}(\mathrm{l}), \mathrm{NO}_{3}^{-}$(l). (c) reduced nitrogen: $\mathrm{NH}_{3}(\mathrm{~g}), \mathrm{NH}_{4}^{+}$(s), $\mathrm{NH}_{3}$ (l), $\mathrm{NH}_{4}^{+}$(l). Numbers to the left (before cloud passage) and right (after) show column mass totals of the gas and aerosol reservoirs.

cel spends in the cloud in this setup is about $450 \mathrm{~s}$ (cloud with approx. $9 \mathrm{~km}$ diameter, $20 \mathrm{~m} \mathrm{~s}^{-1}$ wind speed), and the maximum absolute difference in $\mathrm{SO}_{4}^{2-}$ in the wake of the cloud is $+3.2 \mu \mathrm{g} \mathrm{m}^{-3}$. This means that with an initial $\mathrm{SO}_{2}$ concentration of about $1 \mu \mathrm{g} \mathrm{m}^{-3}$ we generated approximately $7.1 \mathrm{ng} \mathrm{m}^{-3}$ of $\mathrm{SO}_{4}^{2-}$ per second due to aqueous-phase chemistry.

Figure 3 shows the column-total partitioning of mass between gas, aerosol and cloud phase for sulfur and nitrogen compounds during passage of the cloud. Wet deposition was negligibly small for mass calculations in this idealized simulation. Note that only about one third of the column is actually exposed to the cloud. Both, total sulfur and oxidized nitrogen show increases in aerosol mass by $230 \%$ $\left(+2.16 \mathrm{mg}(\mathrm{S}) \mathrm{m}^{-2}\right)$ and $140 \%\left(+0.94 \mathrm{mg}(\mathrm{N}) \mathrm{m}^{-2}\right)$ column total, respectively. Reduced nitrogen shows an increase of $120 \%\left(+2.1 \mathrm{mg}(\mathrm{N}) \mathrm{m}^{-2}\right)$ after cloud passage, as a result of its thermodynamic equilibrium with sulfate and nitrate.

The idealized simulations provide useful insight into the workings of the new coupling and the results are both physically and chemically plausible. Therefore the coupling has 


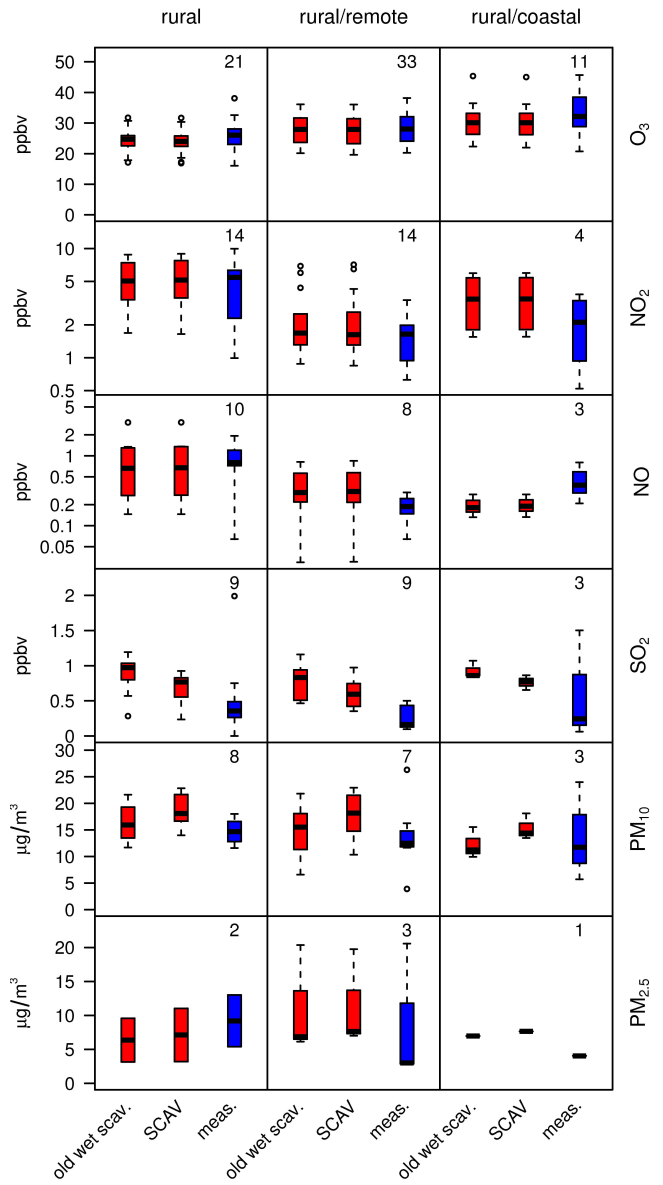

Fig. 4. Boxplots of mean trace gas and particulate matter concentrations of a set of measurement stations averaged over the simulation period. Shown are results from the reference simulation in Knote et al. (2011) (REF), results from a new simulation including aqueous-phase chemistry (SCAV), and measurement data from the EMEP network (meas.). Stations classified according to their representativeness following (Henne et al., 2010). Number of stations used shown in top-right corner.

been applied to a realistic 3-D simulation of air quality over Europe.

\section{Application to a real case}

In Knote et al. (2011), COSMO-ART was extensively evaluated against a number of observational datasets, including measurements of aerosol chemical composition by aerosol mass spectrometry (AMS). While several parameters were simulated with good quality, a number of deficiencies were found including an overestimation of $\mathrm{SO}_{2}$ concentrations compared to surface station observations. From a comparison against aerosol mass spectrometer (AMS, Canagaratna et al., 2007) data it was found that concentrations of sulfate aerosols were too low, while nitrates were biased high. These findings provided strong evidence that wet scavenging of gases and aqueous-phase chemistry were indeed lacking: firstly, the overestimation of ammonium-nitrate aerosols is expected to be reduced since the gas-phase counterparts of ammonium-nitrate, $\mathrm{HNO}_{3}$ and $\mathrm{NH}_{3}$, readily transfer into the aqueous-phase and are therefore efficiently scavenged. Secondly, aerosol sulfate is expected to increase since aqueousphase conversion of $\mathrm{SO}_{2}$ to $\mathrm{SO}_{4}^{2-}$ contributes substantially to measured aerosol sulfate (Walcek and Taylor, 1986; Rasch et al., 2000). To understand the impacts of our addition in a realistic setting we chose to re-simulate one of the evaluation periods from Knote et al. (2011). We picked the autumn 2008 period due to high cloudiness and frequent precipitation events. The setup of the new run is identical to the simulations in Knote et al. (2011), employing a domain with 200 by 190 grid boxes at $0.17^{\circ}$ and 40 vertical levels. A new module to describe SOA formation (Athanasopoulou et al., 2013) has been developed since Knote et al. (2011), and both, the reference run and the one including SCAV, have been conducted using this module. The previous wet scavenging scheme for aerosols has been active in the reference simulation.

\subsection{Comparison against long-term station measurements}

Figure 4 summarizes the impact of the coupling on concentrations of $\mathrm{O}_{3}, \mathrm{NO}_{\mathrm{x}}, \mathrm{SO}_{2}, \mathrm{PM}_{10}$, and $\mathrm{PM}_{2.5}$. Shown are the simulation period mean concentrations of a set of surface station observations throughout Europe from the EMEP network and the corresponding model concentrations for the reference simulation from Knote et al. (2011) and the new version including SCAV. The comparisons are subdivided according to the station classification of Henne et al. (2010), in which stations are categorized according to their representativeness.

Ozone and $\mathrm{NO}_{\mathrm{x}}$ are virtually unaffected by the implementation, which was expected. $\mathrm{SO}_{2}$ shows strong reductions and agrees better with measurements, although it is still above measured concentrations. $\mathrm{PM}_{10}$ is increased in the SCAV run, leading to a slight overestimation compared to measurements. We attribute this to a less efficient scavenging of larger aerosol particles like seasalt, dust or coarse anthropogenic particles compared to the aerosol scavenging scheme used previously. We find a slight increase in total $\mathrm{PM}_{2.5}$ mass at all types of stations.

\subsection{Comparison against reference simulation}

Figure 5 shows the spatial distribution of mean total cloud cover, changes in $\mathrm{SO}_{2}$, and in the chemical composition of sulfate and nitrate aerosol mass. Differences in the mean concentration over the simulation period between the reference and the simulation including SCAV are presented relative to the reference case.

$\mathrm{SO}_{2}$ is reduced by up to $1 \mathrm{ppbv}\left(2.8 \mu \mathrm{g} \mathrm{m}^{-3}\right.$ at STP), with the strongest reductions found over Southern Poland, 


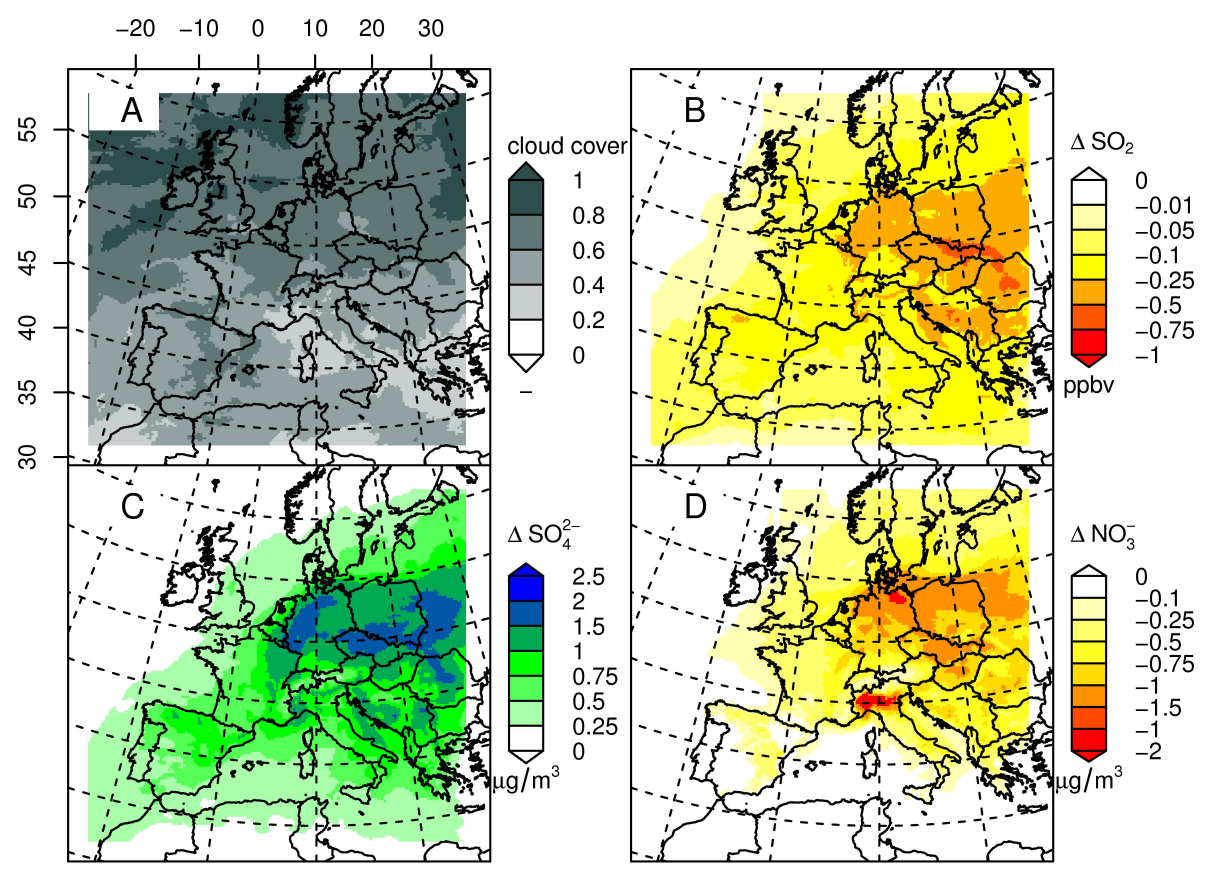

Fig. 5. Maps of mean total cloud cover (A), absolute changes in gas-phase $\mathrm{SO}_{2}(\mathbf{B})$, and in $\mathrm{SO}_{4}^{2-}$ (C) and $\mathrm{NO}_{3}^{-}$aerosol mass (D) due to the inclusion of the new scavenging module. Shown are mean differences (plots $\mathbf{B}, \mathbf{C}, \mathbf{D}$ ) over the whole simulation period.

Northern Slovakia and in the Balkan region. This is reasonable, as these are the regions most strongly polluted in $\mathrm{SO}_{2}$ and hence with the largest reduction potential in absolute terms. Generally, the eastern part of the model domain sees stronger reductions than the west, which can be explained by both, predominant westerly flow advecting pristine air to the western part of the domain, and generally poorer air quality and hence more precursors in Eastern Europe. Furthermore, largest effects are expected in the wake of clouds, for example downstream of the cloudy areas in Central and Northwestern Europe. Sulfate aerosol mass is increased by up to $2.5 \mu \mathrm{g} \mathrm{m}^{-3}$, with the strongest increases again over Eastern Europe, where we already found strongest $\mathrm{SO}_{2}$ reductions. A distinct region of high sulfate increases is visible in the northwestern part of Germany. Assuming a westerly flow, this is just downwind of the densely populated Belgium-Netherlands-Luxemburg (BeNeLux) region, and the heavy industry in the German Ruhr area. Reductions in $\mathrm{NO}_{3}^{-}$aerosol mass are substantial, with reductions between 1 and $1.5 \mu \mathrm{g} \mathrm{m}^{-3}$ over large parts of Germany, Poland and the Baltic region. Even stronger reductions by up to $2 \mu \mathrm{g} \mathrm{m}^{-3}$ on average are found in the Po Valley region. This indicates that an efficient washout of nitric acid is indeed effective to reduce the positive bias identified in our previous simulations for nitrate aerosols. We conclude that magnitude and direction as well as spatial patterns of observed changes in trace gas and aerosol components are reasonable, and will show in the next paragraph that they improve the comparison with measurements of aerosol components.

\subsection{Improvements in aerosol chemical composition}

Information about the chemical composition of ambient aerosol with high temporal resolution (hourly and better) can be inferred for non-refractive particles below $1 \mu \mathrm{m}$ $\left(\mathrm{NR}-\mathrm{PM}_{1}\right)$ using an aerosol mass spectrometer (AMS, Canagaratna et al., 2007). During the simulation period, several AMS instruments had been deployed at a number of stations throughout Europe within a EUCAARI/EMEP measurement campaign. These data allow for a quantitative comparison of the mass of major inorganic species and organic contributions as presented in Knote et al. (2011). The reader is referred to this publication for details about the comparison method and in particular on the application of the AMS transmission function to convert the modal aerosol distributions in COSMO-ART into quantities directly comparable to the measurements. Figure $6 \mathrm{a}, \mathrm{b}$ and Table 5 show that the inclusion of SCAV has considerable impact on the chemical composition.

The overestimation of nitrate compounds found in previous simulations is reduced, which is mostly due to the efficient washout of the $\mathrm{HNO}_{3}$ precursor. Some discrepancy remains, like for example a tendency of the model to retain too much nitrate in the particle phase during daytime (e.g. in Payerne and Melpitz in Fig. 6a or K-Puszta in Fig. 6b). Sulfate aerosol mass increases substantially and now compares better to measured contributions, although at all stations the simulated values are still below the measurements. Together with the overestimation of $\mathrm{SO}_{2}$, this points to a still too 
Table 5. Time-averaged NR- $\mathrm{PM}_{1}$ masses $\left(\mu \mathrm{g} \mathrm{m}^{-3}\right)$ corresponding to the pie charts in Figure $6 \mathrm{a}$, $\mathrm{b}$ for observations (obs.), the reference simulation (ref.) and including SCAV (SCAV).

\begin{tabular}{|c|c|c|c|c|c|c|c|c|c|c|c|c|}
\hline & obs. & $\begin{array}{l}\mathrm{NH}_{4}^{+} \\
\text {ref. }\end{array}$ & SCAV & obs. & $\begin{array}{l}\mathrm{SO}_{4}^{2-} \\
\text { ref. }\end{array}$ & SCAV & obs. & $\begin{array}{l}\mathrm{NO}_{3}^{-} \\
\text {ref. }\end{array}$ & SCAV & obs. & $\begin{array}{l}\text { OA } \\
\text { ref. }\end{array}$ & SCAV \\
\hline Payerne & 1.2 & 1.0 & 0.8 & 1.4 & 0.3 & 0.7 & 2.2 & 3.0 & 1.9 & 5.0 & 3.3 & 2.9 \\
\hline Melpitz & 1.2 & 1.2 & 0.9 & 1.5 & 0.2 & 0.7 & 2.5 & 3.7 & 2.2 & 3.3 & 3.6 & 3.3 \\
\hline Vavihill & 0.8 & 0.6 & 0.5 & 0.9 & 0.2 & 0.3 & 1.9 & 2.0 & 1.2 & 2.8 & 2.5 & 2.3 \\
\hline Hyytiälä & 0.1 & 0.2 & 0.2 & 0.2 & 0.1 & 0.2 & 0.1 & 0.5 & 0.3 & 0.6 & 1.6 & 1.6 \\
\hline K-Puszta & 1.9 & 1.7 & 1.4 & 3.1 & 1.0 & 1.2 & 2.6 & 4.7 & 3.1 & 7.1 & 6.2 & 5.6 \\
\hline
\end{tabular}

slow oxidation of $\mathrm{SO}_{2}$ in the aqueous-phase possibly due to the lack of an explicit representation of several potentially relevant ions ( $\mathrm{Mn}, \mathrm{Fe}, \mathrm{Ca}, \mathrm{K})$ that affect $\mathrm{pH}$ in COSMOART and missing minor oxidation pathways (transition metals, formaldehyde, dichloride ions, Jacobson, 2005). Biases in cloud $\mathrm{pH}$ would also influence the efficiency of oxdiation by $\mathrm{O}_{3}$ (Kreidenweis et al., 2003).

Organic aerosol mass was not changed substantially due to the new coupling. Note the significantly improved agreement with observed values compared to what was presented in Knote et al. (2011). This is the result of a change from the use of the SORGAM module (Schell et al., 2001) to describe the formation of secondary organic aerosols (SOA) to a volatility basis set approach (Athanasopoulou et al., 2013).

There is evidence that SOA can be formed in the aqueousphase, and that these contributions can be substantial (Turpin et al., 2000; Lim et al., 2010; Ervens et al., 2011). As we focused on sulfate, we did not include any of these formation pathways so far.

Overall the relative contributions of the different components to NR-PM 1 show better agreement with AMS measurements due to the inclusion of SCAV, though total mass of $\mathrm{NR}-\mathrm{PM}_{1}$ is slightly reduced. It is possible that this indicates missing sources for submicron aerosols in the model like wrong emission size distributions, or underestimated new particle formation. Further, aerosol growth due to cloud processing could be overestimated. To compare with AMS measurements, the AMS transmission function needs to be applied to the modeled aerosol mass size distribution to accurately represent the particle size range "visible" for the AMS. The analysis of changes in size distribution in the next paragraph shows that the reduction in total $\mathrm{NR}-\mathrm{PM}_{1}$ mass is caused by a shift of mass to larger diameters, resulting in an increased fraction of mass in the accumulation mixed mode not being "seen" by the AMS due to the specific sampling efficiency cut-off of this instrument at about $1 \mu \mathrm{m}$. The comparison with $\mathrm{PM}_{2.5}$ measurements already showed that the mass is not lost, but rather redistributed. AMS instruments measuring the whole size range of $\mathrm{PM}_{2.5}$ as currently being developed at the Paul Scherrer Institute, Switzerland, will simplify the comparison between observations and modeling results.

\subsection{Effects on aerosol size distribution}

In Knote et al. (2011) we investigated model performance for number concentration size distributions at a number of stations throughout Europe for which Asmi et al. (2011) reported a homogenized measurement dataset. Here we use the same set of stations, but compare distributions of volume rather than of number concentrations to better understand the effect of the new scavenging scheme on aerosol mass. We only show modelled values, as the dataset in Asmi et al. (2011) is considered optimal only between diameters of 20 and $200 \mathrm{~nm}$, which is outside of the range where volume concentration size distributions peak.

Figure 7 presents the total volume concentrations for the reference case and the new modeling system as function of the particle diameter over a range between $20 \mathrm{~nm}$ up to $10 \mu \mathrm{m}$. Typical transmission functions for an AMS, a $\mathrm{PM}_{2.5}$ and a $\mathrm{PM}_{10}$ inlet system (as calculated in Knote et al., 2011) are given in the figure for comparison. Only the modes containing secondary particles (fresh and mixed Aitken and accumulation modes) were used here to isolate the effect of cloud processing from simple washout which is happening in the remaining modes (coarse, seasalt, dust).

At a number of stations shown in Fig. 7, a shift of the size distribution towards larger diameters is visible, which is the expected result of the cloud processing of aerosols. Especially the stations in rather polluted environments (Ispra, K-Puszta, Kosetice) show pronounced changes in size distribution, which is expected to improve their comparison with measurements, as we found in general too small particles at these stations in Knote et al. (2011). At very clean stations instead (Mace Head, Birkenes) no distinct changes in volume concentration size distributions are observed.

A sensitivity simulation where the maximum CDNC used in activation and evaporation calculations has been doubled $\left(N_{0}=400 \mathrm{~cm}^{-3}\right)$ showed no noticeable effect on the changes in size distributions.

\subsection{Wet deposition}

To understand the quality of the aerosol and trace gas sink term due to wet scavenging, we compared our simulations against wet deposition station data from the 

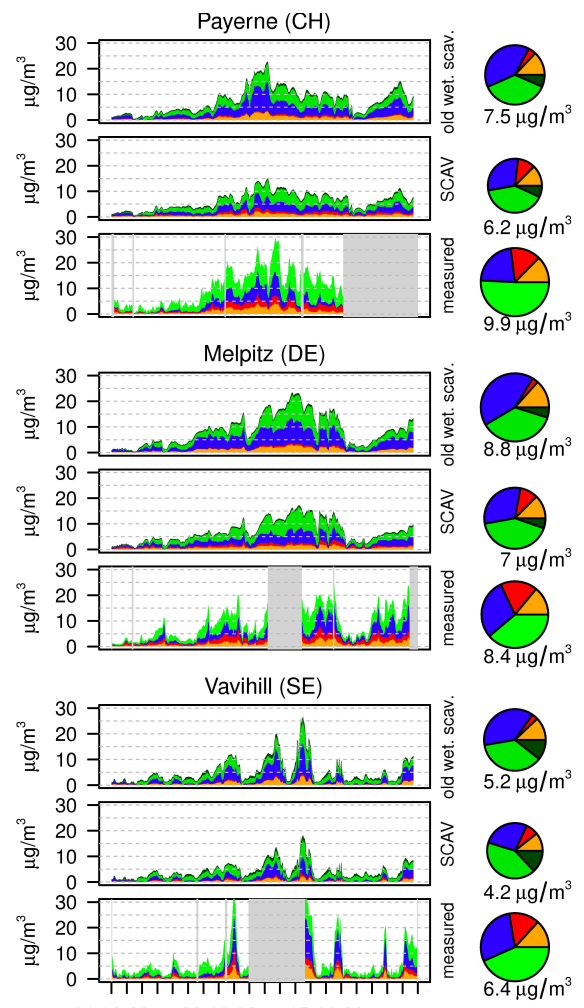

$\begin{array}{lll}01.10 .08 & 08.10 .08 \quad 15.10 .08\end{array}$

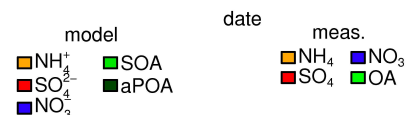

(a)
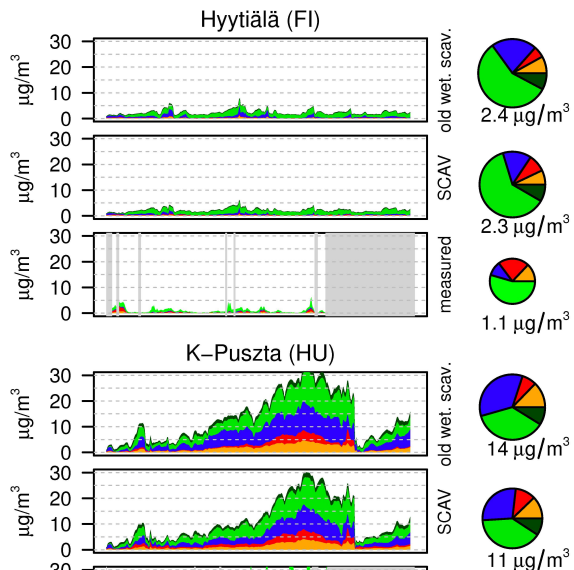

हE 20

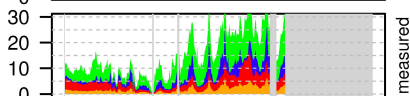

$01.10 .08 \quad 08.10 .08 \quad 15.10 .08$

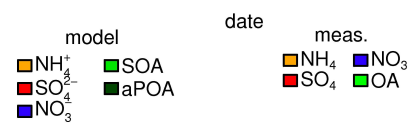

(b)

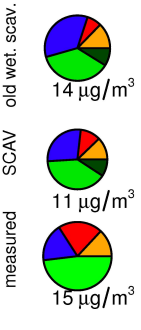

Fig. 6. (a) Timeline of chemical composition of non-refractory PM below $1 \mu \mathrm{m}$ (top: reference simulation, middle: simulation with SCAV, bottom: measured by AMS) during autumn 2008. Pie charts give mean over time period (size of pie relates total mass). Measured OA should be compared with the sum of modeled aPOA + SOA. Gray shaded areas mask times without measurement data. (b) As (a) but for different stations.

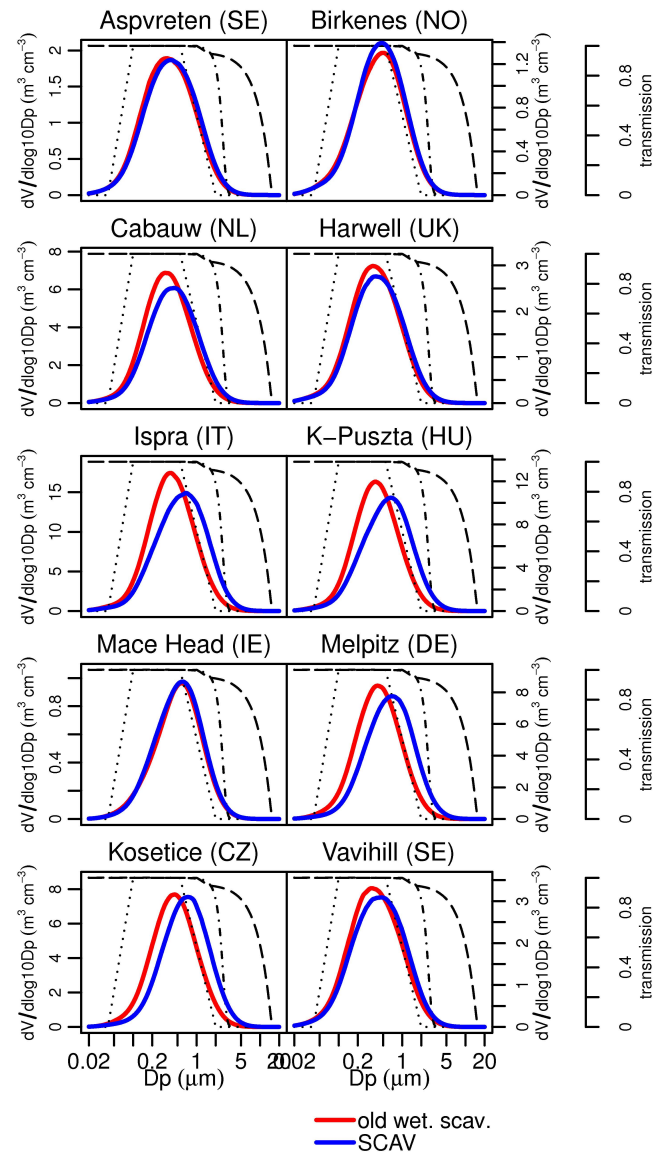

Fig. 7. Modeled aerosol volume concentration size distributions at selected stations for the autumn 2008 period. Reference simulation (red) and a simulation including SCAV and cloud processing (blue) are shown as thick solid lines. For reference the transmission functions of an AMS (dotted line), a $\mathrm{PM}_{2.5}$ (dash-dotted line) and a $\mathrm{PM}_{10}$ (dashed line) inlet system as calculated in Knote et al. (2011) are given as well. Shown are only the volume contributions of the modes containing secondary components (fresh and mixed Aitken and accumulation modes).

European Monitoring and Evaluation Programme (EMEP, http://www.emep.int). 80 stations throughout Europe provided daily sums of wet deposited masses of $\mathrm{NO}_{3}^{-}, \mathrm{NH}_{4}^{+}$and $\mathrm{SO}_{4}^{2-}$, usually measured by ion chromatography (Aas et al., 1996), as well as average precipitation acidity (pH) and accumulated precipitation. Figure 8 shows a comparison of precipitation, $\mathrm{pH}$ and the wet deposited mass totals over the simulated period. There is reasonable agreement with precipitation $\mathrm{pH}$, with a mean value of 5.4 for measured and 6.0 for modelled values. Most of the comparisons of wet deposition with single station measurements lie within a factor of 5 . Deposited nitrate and ammonia mass generally correspond to measurements within a factor of 2 . Only sulfate mass shows a stronger underestimation, which reflects the still too low sulfate aerosols concentrations. 

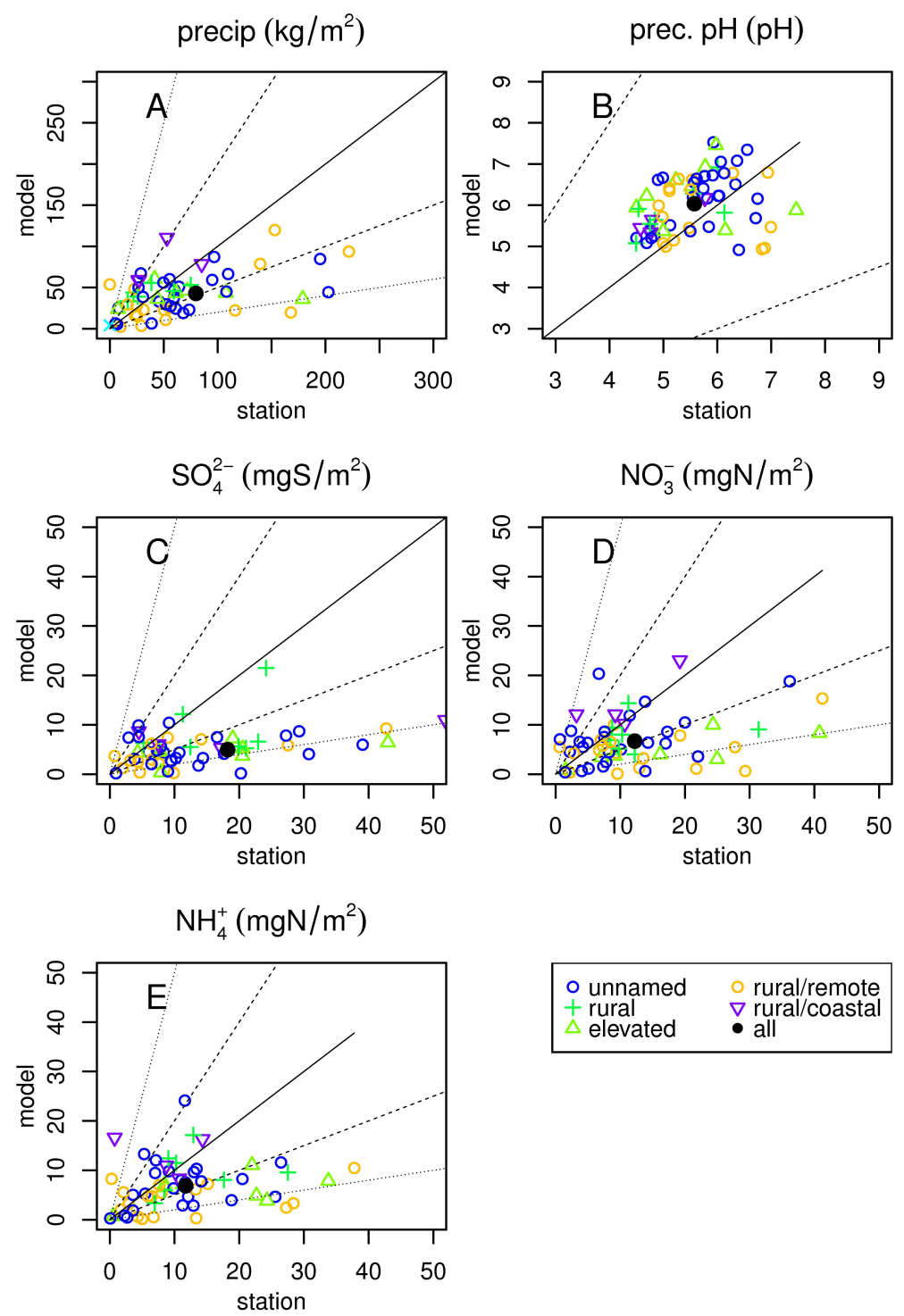

Fig. 8. Scatterplots of accumulated precipitation $(\mathbf{A})$, rain $\mathrm{pH}(\mathbf{B})$, and wet deposited mass of $\mathrm{SO}_{4}^{2-}(\mathbf{C}), \mathrm{NO}_{3}^{-}(\mathbf{D})$, and $\mathrm{NH}_{4}^{+}(\mathbf{E})$. Each hollow symbol represents the comparison between the measured mass total (average in case of $\mathrm{pH}$ ), over the simulation period against the modeled one at a single station. Symbols are categorized according to a station representativeness classification by Henne et al. (2010), which is shown by different colors/symbols. Filled black circles represent the arithmetic mean over all comparisons. Lines are drawn to help estimate over/underestimation factors: solid $=1: 1$, dashed $=2: 1$ and dotted $=5: 1$.

We find an average underprediction of accumulated precipitation by the model by a factor of 2 . Hence we conclude that the underprediction of wet deposited mass of nitrate and ammonium, and part of the underestimation of sulfate wet deposition, is likely reasoned by insufficiencies of the meteorological simulation. The stochastic nature of precipitation contributes to the strong scatter of the comparison for such a short period (20 days) (Fig. 8a) - and would arguably be reduced when simulating a longer time period. Also, very low precipitation intensities (drizzle) may not be registered by the instrumentation as precipitation event due to the measurement principle, which requires the opening of a lid (Aas et al.,
1996). One possibility to circumvent the problem of statistical undersampling which does not involve simulating longer periods is to calculate the mean deposition (as arithmetic mean over all stations, black circles in Fig. 8), which can serve as a proxy for total wet deposition in Europe. There, $\mathrm{SO}_{4}^{2-}$ is underestimated by a factor of 2-3. Model and measurements show better agreement for $\mathrm{NO}_{3}^{-}$and $\mathrm{NH}_{4}^{+}$, where the underestimations are below a factor of 2. Results shown in Gong et al. (2006) for a comparable modeling system indicated similar underpredictions. 


\section{Discussion}

\subsection{Limitations of the current implementation}

Despite the comparatively high degree of complexity of our scheme, three major omissions and the reasons need to be mentioned:

Firstly, no scavenging of aerosols or trace gases by ice crystals or snow flakes has been implemented so far, although SCAV does allow such a coupling. The species most affected by such a scavenging is $\mathrm{HNO}_{3}$ (Chang, 1984; Baltensperger et al., 1991; Abbatt, 1997), and its magnitude can be substantial under free-tropospheric conditions. Neu and Prather (2012) recently highlighted the importance of this process for a correct description of $\mathrm{HNO}_{3}$ lifetimes and subsequently of upper troposphere $\mathrm{O}_{3}$ concentrations. For studies of the lower troposphere this is, however, of much lesser importance and arguably negligible. It can become important, however, if a winter period is simulated. In the light of the additional computational demand of such a coupling (twice the number of transported species and more chemistry) we refrained so far to include this coupling, but it would be important for studies of the upper troposphere/polar regions.

Secondly, COSMO-ART has recently been coupled to the experimental two-moment microphysics scheme of Seifert and Beheng (2006) to simulate aerosol indirect effects on clouds (Bangert et al., 2011), which would allow a much more detailed description of the nucleation scavenging processes for aerosols. Currently, SCAV employs an empiric method derived from measurements of interstitial aerosol within clouds, which completely disregards variability in activation due to aerosol characteristics other than size. However we have chosen to couple SCAV with COSMO-ART in a way that is applicable in typical/operational COSMOART setups. As the parametrization of Bangert et al. (2011) requires the Seifert and Beheng (2006) two-moment microphysics scheme, this would not be the case. Such a coupling is nonetheless an important topic for future studies of aerosol cloud interactions.

Thirdly, our scheme has only been implemented for gridresolved clouds. A full coupling would be non-trivial and exceeds the scope of this work.

\subsection{Comparison with other model systems}

The extensive review of cloud chemistry and scavenging representations in current regional model systems in Gong et al. (2011) facilitates a comparison of the new coupling with implementations in other modeling systems. Our coupling includes a kinetic description of the transfer processes between gas-phase and droplet and therefore does not assume equilibrium, neither for the transfer into cloud droplets nor into rain droplets. This is expected to be beneficial especially for high-resolution applications where the time-steps drop below $10 \mathrm{~s}$, where clouds may develop and disappear rapidly and where equilibrium might not be achieved. Only one other model (AURAMS, Gong et al., 2006; Smyth et al., 2009) uses such a physical approach. Nucleation scavenging of aerosols is parametrized by an empirically derived activation curve, which we have coupled with the condensation tendency derived from the microphysics module. This is a more realistic approach than models defining complete modes as activated fraction once a cloud is formed in a grid cell (CMAQ, Byun and Schere, 2006). However, models including a physically based activation scheme like WRFChem (http://ruc.noaa.gov/wrf/WG11/), or GATOR (Jacobson et al., 1996; Jacobson, 1997a,b), will be more realistic in their description of this process as they can take into account the size distribution and chemical composition of the aerosols. Impaction scavenging of aerosols in SCAV takes into account both the particle and an estimated droplet size distribution, as the COSMO microphysics scheme is a bulk scheme and cannot deliver a "real" droplet size distribution. We have seen from the review in Gong et al. (2011) that this method is one of the more detailed methods compared to what is implemented in other models, though can be improved with realistic cloud droplet size distributions. The aqueous-phase chemistry mechanism used in this study can be classified (according to Gong et al., 2011) as a condensed mechanism focusing on sulfur oxidation. However, it is up to the user to choose the level of complexity, as the KPP-based chemistry allows for sufficient flexibility. When choosing the full mechanism as described in Tost et al. (2006) the coupled system can be ranked in the class of "more complete" mechanisms (Gong et al., 2011). Only few model systems consider transport of in-cloud substances, and the fact that the chemical composition of rain droplets is a prognostic quantity in our approach is to our knowledge a unique feature.

\section{Conclusions}

We have coupled COSMO-ART with SCAV, a scheme accounting for wet scavenging of gases and aerosols, and aqueous-phase chemistry. The scheme had to be extended to account for the use of a module originally developed for global models in a regional model with grid resolutions in the kilometer range and time-steps in the order of seconds. Microphysical tendencies derived in the COSMO meteorological core are used to link condensation, transfer and evaporation processes with the underlying meteorology. Cloud liquid water and precipitation chemical composition are now transported quantities, consistent with meteorology. A flexible link between gas-phase, aerosols and liquid-phase components combined with the use of KPP in SCAV allow for flexible extension of the coupling.

Results from a 2-D flow-over-hill study show that the conversion of $\mathrm{SO}_{2}$ to sulfate aerosols is efficient with up to $500 \%$ increase in total sulfate leewards the mountain, corresponding to a mean production rate of $7.1 \mathrm{ng} \mathrm{m}^{-3} \mathrm{~s}^{-1}$. 
Comparison of the results of a realistic simulation with measurements over Europe indicate that $\mathrm{SO}_{2}$ is reduced by $0.3 \mathrm{ppbv}$ on average, the reductions nonetheless not being large enough to reach measured concentrations. Slight increases in $\mathrm{PM}_{10}$ are found which are due to a less efficient scavenging of coarse particles compared to the old wet scavenging scheme for aerosols. $\mathrm{PM}_{2.5}$ mass was mostly unchanged.

In comparison against the reference simulation we find increases in total particulate sulfate of up to $+2.5 \mu \mathrm{g} \mathrm{m}{ }^{-3}$ mostly in Eastern Europe in regions with elevated $\mathrm{SO}_{2}$ emissions. Particulate nitrate showed reductions over large regions up to $-1 \mu \mathrm{g} \mathrm{m}^{-3}$, up to $-2 \mu \mathrm{g} \mathrm{m}^{-3}$ in the Po Valley and Nothern Germany. The chemical composition of NR-PM1 changed notably, mostly due to a reduction in nitrate components and an increase in sulfate, and now matches observations from aerosol mass spectrometers better. Inclusion of SCAV resulted in a slight decrease in total NR-PM1 mass, due to a shift of mass from the sub- $\mathrm{PM}_{1}$ diameter region to the region between $\mathrm{PM}_{1}$ and $\mathrm{PM}_{2.5}$. Wet deposition amounts are underestimated, for sulfate on average by a factor of $2-$ 3 , and within a factor of 2 for nitrate and ammonium when compared to measurements. A comparable underestimation of modelled precipitation can explain this and suggests that the wet removal process itself is in fact well represented. Precipitation $\mathrm{pH}$ is in reasonable agreement with measurements.

Limitations of the coupling have been mentioned which need to be taken into account in case the model is to be applied for different purposes. The coupled system presented here provides a framework for further studies of cloud processing, aqueous-phase production of secondary organic aerosols and wet deposition with COSMO-ART.

Acknowledgements. We thank Holger Tost, Johannes GutenbergUniversitaet Mainz, Germany, for his willingness to provide source code and updates for the SCAV module and his kindness in responding to our questions. The Swiss National Science Foundation is acknowledged for partly financing the IPAZIA computational cluster (project 206021_128754). The IPAZIA team is kindly acknowledged for their support. The members of the working group "Spurenstoffmodellierung und Klimaprozesse" led by Bernhard Vogel, the main developers of COSMO-ART, are thanked for their ongoing support of our efforts. We thank two anonymous reviewers for valuable comments and suggestions.

Edited by: T. Butler

\section{References}

Aas, W., Berg, T., Dye, C., Hanssen, J., Krognes, T., Munthe, J., Reissell, A., Schaug, J., Schmidbauer, N., Semb, A., Tørseth, K., and Thelle, H. U.: EMEP manual for sampling and chemical analysis, Norwegian Institute for Air Research, Kjeller, EMEP/CCC-Report 1/95, available at: http://www.nilu.no/ projects/ccc/manual/, (last access: February 2012), 1996.

Abbatt, J.: Interaction of $\mathrm{HNO}_{3}$ with water-ice surfaces at temperatures of the free troposphere, Geophys. Res. Lett., 24, 1479$1482,1997$.

Ackermann, I. J., Hass, H., Memmesheimer, M., Ebel, A., Binkowski, F. S., and Shankar, U.: Modal aerosol dynamics model for Europe: development and first applications, Atmos. Environ., 32, 2981-2999, 1998.

Albrecht, B.: Aerosols, cloud microphysics, and fractional cloudiness, Science, 245, 1227, doi:10.1126/science.245.4923.1227, 1989.

Asmi, A., Wiedensohler, A., Laj, P., Fjaeraa, A.-M., Sellegri, K., Birmili, W., Weingartner, E., Baltensperger, U., Zdimal, V., Zikova, N., Putaud, J.-P., Marinoni, A., Tunved, P., Hansson, H.C., Fiebig, M., Kivekäs, N., Lihavainen, H., Asmi, E., Ulevicius, V., Aalto, P. P., Swietlicki, E., Kristensson, A., Mihalopoulos, N., Kalivitis, N., Kalapov, I., Kiss, G., de Leeuw, G., Henzing, B., Harrison, R. M., Beddows, D., O’Dowd, C., Jennings, S. G., Flentje, H., Weinhold, K., Meinhardt, F., Ries, L., and Kulmala, M.: Number size distributions and seasonality of submicron particles in Europe 2008-2009, Atmos. Chem. Phys., 11, 5505-5538, doi:10.5194/acp-11-5505-2011, 2011.

Athanasopoulou, E., Vogel, H., Vogel, B., Tsimpidi, A., Pandis, S. N., Knote, C., and Fountoukis, C.: Modeling the meteorological and chemical effects of secondary organic aerosols during an EUCAARI campaign, Atmos. Chem. Phys., 13, 625-645, doi:10.5194/acp-13-625-2013, 2013.

Baldauf, M. and Schulz, J. P.: Prognostic Precipitation in the Lokal-Modell (LM) of DWD, COSMO newsletter, http://www. cosmo-model.org, (last access: January 2013), 4, 177-180, 2004.

Baldauf, M., Seifert, A., Förstner, J., Majewski, D., Raschendorfer, M., and Reinhardt, T.: Operational convective-scale numerical weather prediction with the COSMO model: description and sensitivities, Mon. Weather Rev., 139, 3887-3905, doi:10.1175/MWR-D-10-05013.1, 2011.

Baltensperger, U., Gäggeler, H., Jost, D., Nieveler, U., and Schwikowski, M.: In-cloud scavenging by snow at a high-alpine site, J. Aerosol Sci., 22, S541-S544, 1991.

Bangert, M., Kottmeier, C., Vogel, B., and Vogel, H.: Regional scale effects of the aerosol cloud interaction simulated with an online coupled comprehensive chemistry model, Atmos. Chem. Phys., 11, 4411-4423, doi:10.5194/acp-11-4411-2011, 2011.

Byun, D. W. and Schere, K. L. : Review of the governing equations, computational algorithms, and other components of the Models3 Community Multiscale air quality (CMAQ) modeling system, Applied Mechanics Review, 55, 51-77, 2006.

Canagaratna, M., Jayne, J., Jimenez, J., Allan, J., Alfarra, M., Zhang, Q., Onasch, T., Drewnick, F., Coe, H., Middlebrook, A., Delia, A., Williams, L. R., Trimborn, A. M., Northway, M. J., DeCarlo, P. F., Kolb, C. E., Davidovits, P., and Worsnop, D. R.: Chemical and microphysical characterization of ambient aerosols with the aerodyne aerosol mass spectrometer, Mass Spectrom. Rev., 26, 185-222, 2007. 
Chang, T.: Rain and snow scavenging of $\mathrm{HNO}_{3}$ vapor in the atmosphere, Atmos. Environ., 18, 191-197, 1984.

Cotton, W., Bryan, G., and van den Heever, S.: Cumulonimbus clouds and severe convective storms, Int. Geophys., 99, 315-454, 2011.

Damian, V., Sandu, A., Damian, M., Potra, F., and Carmichael, G.: The kinetic preprocessor KPP-a software environment for solving chemical kinetics, Comput. Chem. Eng., 26, 1567-1579, 2002.

Doms, G., Förstner, J., Heise, E., Herzog, H.-J., Mironov, D., Raschendorfer, M., Reinhardt, T., Ritter, B., Schrodin, R., Schulz, J.-P., and Vogel, G.: A description of the nonhydrostatic regional COSMO model, Part II: Physical parameterization, Tech. rep., Deutscher Wetterdienst, Offenbach, Germany, 2011.

Donahue, N., Robinson, A., Stanier, C., and Pandis, S.: Coupled partitioning, dilution, and chemical aging of semivolatile organics, Environ. Sci. Technol., 40, 2635-2643, 2006.

Ervens, B., Carlton, A., Turpin, B., Altieri, K., Kreidenweis, S., and Feingold, G.: Secondary organic aerosol yields from cloudprocessing of isoprene oxidation products, Geophys. Res. Lett., 35, L02816, doi:10.1029/2007GL031828, 2008.

Ervens, B., Turpin, B. J., and Weber, R. J.: Secondary organic aerosol formation in cloud droplets and aqueous particles (aqSOA): a review of laboratory, field and model studies, Atmos. Chem. Phys., 11, 11069-11102, doi:10.5194/acp-1111069-2011, 2011.

Feichter, J., Kjellström, E., Rodhe, H., Dentener, F., Lelieveldi, J., and Roelofs, G.: Simulation of the tropospheric sulfur cycle in a global climate model, Atmos. Environ., 30, 1693-1707, 1996.

Feingold, G. and Kreidenweis, S.: Does cloud processing of aerosol enhance droplet concentrations?, J. Geophys. Res., 105, 2435124361, doi:doi:10.1029/2000JD900369, 2000.

Fountoukis, C. and Nenes, A.: ISORROPIA II: a computationally efficient thermodynamic equilibrium model for $\mathrm{K}^{+}$. $\mathrm{Ca}^{2+}-\mathrm{Mg}^{2+}-\mathrm{NH}_{4}^{+}-\mathrm{Na}^{+}-\mathrm{SO}_{4}^{2-}-\mathrm{NO}_{3}^{-}-\mathrm{Cl}^{-}-\mathrm{H}_{2} \mathrm{O}$ aerosols, Atmos. Chem. Phys., 7, 4639-4659, doi:10.5194/acp-7-4639-2007, 2007.

Gassmann, A.: Case studies with the 2-timelevel scheme and prognostic precipitation, COSMO newsletter, http://www. cosmo-model.org, (last access: February 2012), 3, 173-176, 2003.

Geiger, H., Barnes, I., Bejan, I., Benter, T., and Spittler, M.: The tropospheric degradation of isoprene: an updated module for the regional atmospheric chemistry mechanism, Atmos. Environ., 37, 1503-1519, 2003.

Gong, W., Dastoor, A., Bouchet, V., Gong, S., Makar, P., Moran, M., Pabla, B., Ménard, S., Crevier, L., Cousineau, S., and Venkatesh, S.: Cloud processing of gases and aerosols in a regional air quality model (AURAMS), Atmos. Res., 82, 248-275, 2006.

Gong, W., Stroud, C., and Zhang, L.: Cloud processing of gases and aerosols in air quality modeling, Atmosphere, 2, 567-616, 2011.

Hegg, D. and Hobbs, P.: Oxidation of sulfur dioxide in aqueous systems with particular reference to the atmosphere, Atmos. Environ., 12, 241-253, 1978.

Henne, S., Brunner, D., Folini, D., Solberg, S., Klausen, J., and Buchmann, B.: Assessment of parameters describing representativeness of air quality in-situ measurement sites, Atmos. Chem. Phys., 10, 3561-3581, doi:10.5194/acp-10-3561-2010, 2010.
Hong, S.-Y., Dudhia, J., and Chen, S.-H.: A revised approach to ice microphysical processes for the bulk parameterization of clouds and precipitation, Mon. Weather Rev., 132, 103-120, 2004.

Jacobson, M., Lu, R., Turco, R. P., and Toon, O. B.: Development and application of a new air pollution modeling system-part I: Gas-phase simulations, Atmos. Environ., 30, 1939-1963, 1996.

Jacobson, M.: Development and application of a new air pollution modeling system-II: Aerosol module structure and design, Atmos. Environ., 31, 131-144, 1997.

Jacobson, M.: Development and application of a new air pollution modeling system-Part III: Aerosol-phase simulations, Atmos. Environ., 31 (4), 587-608, 1997.

Jacobson, M.: Fundamentals of Atmospheric Modeling, Cambridge University Press, Cambridge University Press, New York, USA, 2005.

Jöckel, P., Sander, R., Kerkweg, A., Tost, H., and Lelieveld, J.: Technical Note: The Modular Earth Submodel System (MESSy) - a new approach towards Earth System Modeling, Atmos. Chem. Phys., 5, 433-444, doi:10.5194/acp-5-433-2005, 2005.

Kerminen, V. and Wexler, A.: Post-fog nucleation of $\mathrm{H}_{2} \mathrm{SO}_{4}^{2-}-\mathrm{H}_{2} \mathrm{O}$ particles in smog, Atmos. Environ., 28, 2399-2406, 1994.

Knote, C., Brunner, D., Vogel, H., Allan, J., Asmi, A., Äijälä, M., Carbone, S., van der Gon, H. D., Jimenez, J. L., KiendlerScharr, A., Mohr, C., Poulain, L., Prévôt, A. S. H., Swietlicki, E., and Vogel, B.: Towards an online-coupled chemistry-climate model: evaluation of trace gases and aerosols in COSMO-ART, Geosci. Model Dev., 4, 1077-1102, doi:10.5194/gmd-4-10772011, 2011.

Kreidenweis, S., Walcek, C., Feingold, G., Gong, W., Jacobson, M., Kim, C., Liu, X., Penner, J., Nenes, A., and Seinfeld, J.: Modification of aerosol mass and size distribution due to aqueous-phase $\mathrm{SO}_{2}$ oxidation in clouds: Comparisons of several models, J. Geophys. Res., 108, 4213, doi:10.1029/2002JD002697, 2003.

Lim, H., Carlton, A., and Turpin, B.: Isoprene forms secondary organic aerosol through cloud processing: model simulations, Environ. Sci. Technol., 39, 4441-4446, 2005.

Lim, Y. B., Tan, Y., Perri, M. J., Seitzinger, S. P., and Turpin, B. J.: Aqueous chemistry and its role in secondary organic aerosol (SOA) formation, Atmos. Chem. Phys., 10, 10521-10539, doi:10.5194/acp-10-10521-2010, 2010.

Lohmann, U. and Feichter, J.: Global indirect aerosol effects: a review, Atmos. Chem. Phys., 5, 715-737, doi:10.5194/acp-5-7152005, 2005.

Lopez, P.: Implementation and validation of a new prognostic large-scale cloud and precipitation scheme for climate and dataassimilation purposes, Q. J. Roy. Meteorol. Soc., 128, 229-257, 2002.

Lord, S., Willoughby, H., and Piotrowicz, J.: Role of a parameterized ice-phase microphysics in an axisymmetric, nonhydrostatic tropical cyclone model, J. Atmos. Sci., 41, 2836-2848, 1984.

Mason, B.: The Physics of Clouds, Claredon, Oxford, 1971.

Neu, J. L. and Prather, M. J.: Toward a more physical representation of precipitation scavenging in global chemistry models: cloud overlap and ice physics and their impact on tropospheric ozone, Atmos. Chem. Phys., 12, 3289-3310, doi:10.5194/acp-12-32892012, 2012.

Orlanski, I.: A rational subdivision of scales for atmospheric processes, B. Am. Meteorol. Soc., 56, 527-530, 1975. 
Pruppacher, H. and Jaenicke, R.: The processing of water vapor and aerosols by atmospheric clouds, a global estimate, Atmos. Res., 38, 283-295, 1995.

Rasch, P., Barth, M., Kiehl, J., Schwartz, S., and Benkovitz, C.: A description of the global sulfur cycle and its controlling processes in the National Center for Atmospheric Research Community Climate Model, Version 3, J. Geophys. Res., 105, 1367-1385, 2000.

Riemer, N., Vogel, H., Vogel, B., and Fiedler, F.: Modeling aerosols on the mesoscale- $\gamma$ : treatment of soot aerosol and its radiative effects, J. Geophys. Res., 108, 4601, doi:10.1029/2003JD003448, 2003.

Riemer, N., Vogel, H., and Vogel, B.: Soot aging time scales in polluted regions during day and night, Atmos. Chem. Phys., 4, 1885-1893, doi:10.5194/acp-4-1885-2004, 2004.

Rinke, R.: Parametrisierung des Auswaschens von Aerosolpartikeln durch Niederschlag, PhD thesis, Inst. für Meteorol. und Klimaforsch. der Univ. Karlsruhe (TH), Karlsruhe, Germany, 2008.

Sander, R., Kerkweg, A., Jöckel, P., and Lelieveld, J.: Technical note: The new comprehensive atmospheric chemistry module MECCA, Atmos. Chem. Phys., 5, 445-450, doi:10.5194/acp-5445-2005, 2005.

Schell, B., Ackermann, I., Hass, H., Binkowski, F., and Ebel, A.: Modeling the formation of secondary organic aerosol within a comprehensive air quality model system, J. Geophys. Res., 106, 28275-28293, 2001.

Seifert, A. and Beheng, K.: A two-moment cloud microphysics parameterization for mixed-phase clouds. Part 1: Model description, Meteorol. Atmos. Phys., 92, 45-66, 2006.

Seinfeld, J. and Pandis, S.: Atmospheric chemistry and physics: from air pollution to climate change, Wiley Interscience Publications, Wiley, New York, USA, 2006.

Slinn, W.: Precipitation scavenging, in: Atmospheric Science and Power Production, US DOE Tech. Info. Center, Oak Ridge, TN, USA, 466-532, 1984.

Smyth, S. C., Jiang, W., Roth, H., Moran, M. D., Makar, P. A., Yang, F., Bouchet, V. S., and Landry, H.: A comparative performance evaluation of the AURAMS and CMAQ air quality systems, Atmos. Environ., 43, 1059-1070, 2009.
Stockwell, W., Middleton, P., Chang, J., and Tang, X.: The second generation regional acid deposition model chemical mechanism for regional air quality modeling, J. Geophys. Res., 95, 16343, 1990.

Tao, W.: An ice-water saturation adjustment, Mon. Weather Rev., 117, 231-235, 1989.

Tost, H., Jöckel, P., Kerkweg, A., Sander, R., and Lelieveld, J.: Technical note: A new comprehensive SCAVenging submodel for global atmospheric chemistry modelling, Atmos. Chem. Phys., 6, 565-574, doi:10.5194/acp-6-565-2006, 2006.

Turpin, B., Saxena, P., and Andrews, E.: Measuring and simulating particulate organics in the atmosphere: problems and prospects, Atmos. Environ., 34, 2983-3013, 2000.

Vogel, B., Vogel, H., Bäumer, D., Bangert, M., Lundgren, K., Rinke, R., and Stanelle, T.: The comprehensive model system COSMO-ART - Radiative impact of aerosol on the state of the atmosphere on the regional scale, Atmos. Chem. Phys., 9, 86618680, doi:10.5194/acp-9-8661-2009, 2009.

Volken, M. and Schumann, T.: A critical review of below-cloud aerosol scavenging results on Mt. Rigi, Water, Air Soil Pollut., 68, 15-28, doi:10.1007/BF00479390, 1993.

Walcek, C. and Taylor, G.: A theoretical method for computing vertical distributions of acidity and sulfate production within cumulus clouds, J. Atmos. Sci., 43, 339-355, 1986.

Wurzler, S., Reisin, T., and Levin, Z.: Modification of mineral dust particles by cloud processing and subsequent effects on drop size distributions, J. Geophys. Res., 105, 4501-4512, 2000.

Zhang, Y., Kreidenweis, S., and Feingold, G.: Stratocumulus processing of gases and cloud condensation nuclei 2. Chemistry sensitivity analysis, J. Geophys. Res., 104, 16061-16080, 1999.

Zhao, M. and Austin, P.: Life cycle of numerically simulated shallow cumulus clouds. Part I: Transport, J. Atmos. Sci., 62, 12691290, 2005. 